\title{
PENERIMAAN KONSUMEN DAN COMPLIANCE MAKANAN SIAP MAKAN COOKIES BERBASIS BAHAN LOKAL UNTUK ANAK BATITA WASTING
}

\author{
Arnelia', Lilik Kustiyah², Mira Dewi², Dyah Santi Puspitasari' \\ ${ }_{1}$ Pusat TTK-EK, Balitbangkes Kemkes RI \\ 2 Departemen Gizi Masyarakat, FEMA IPB \\ arnel_518@yahoo.com
}

\begin{abstract}
ABSTRAK
Dalam pedoman penanganan anak gizi buruk dinyatakan bahwa anak wasting perlu diberi Pemberian Makanan Tambahan Pemulihan (PMT-Pemulihan). Komposisi gizi makanan tambahan untuk anak wasting berbeda dengan anak gizi buruk maupun anak sehat. Tujuan penelitian adalah menilai penerimaan konsumen dan compliance anak batita wasting terhadap Ready to Use Food (RUF) bentuk cookies berbasis bahan lokal. Intervensi dengan disain Randomized Controlled Trial (RCT), dilakukan di Klinik Gizi Bogor pada 78 anak batita wasting. Separuh anak diberi cookies berbasis bahan lokal dan separuh lainnya diberi biskuit fabrikan, dan isoenergi sekitar 400 kkal perhari selama 12 minggu. Produksi cookies dilakukan di BreAD Unit- SEAFAST Center-IPB, Bogor. Hasil penelitian menunjukkan komposisi per 1000 kkal cookies adalah: protein $18.15 \mathrm{~g}$, lemak $54.97 \mathrm{~g}$, dan karbohidrat $110.51 \mathrm{~g}$. Uji penerimaan oleh 68 panelis menunjukkan bahwa lebih dari 90 persen menyatakan aroma cookies harum dan tekstur renyah, lebih dari dua pertiga menyatakan tidak terasa after taste Fe dan $\mathrm{Zn}$, serta separuh menyukai warna kuning cookies. Compliance pada bulan pertama tidak berbeda antara kelompok yang mendapat cookies dengan biskuit, rerata yang dihabiskan masing-masing 83 persen dan 79 persen ( $p>0.05$ ). Pada bulan kedua dan ketiga terdapat perbedaan kepatuhan. Rerata cookies dan biskuit yang dihabiskan masing-masing adalah 82 persen dan 73 persen $(p<0.05)$ pada bulan kedua dan 80 persen serta 72 persen $(p<0.05)$ pada bulan ketiga. Cookies berbasis bahan lokal dapat diterima konsumen berdasarkan penilaian aroma, warna, rasa dan tekstur serta dapat digunakan sebagai alternatif makanan tambahan bagi anak batita wasting.
\end{abstract}

Keywords: wasting, makanan siap makan, RCT, suplemen pangan, kepatuhan

\section{ABSTRACT \\ FOOD PREFERENCE TEST AND THE COMPLINCE OF LOCAL BASED READY TO USE FOOD COOKIES FOR UNDER THREE YEARS OLD WASTING}

According to the guidelines of the Indonesian Ministry of Health 2011, wasted children should be given supplementary feeding. Nutrition composition of supplementary foods for those who are wasting are not the same as severely malnourished as well as wellnourished children. This study aimed to assess food preference test and compliance among wasting children aged under three years given local based cookies as compared to biscuit one. A Randomized Controlled Trial (RCT) design was used among 86 wasted children in Nutrition Clinic Bogor. One group received investigated cookies while the other received biscuit that available in the market, isoenergy around $400 \mathrm{kcal}$ per day during 12 weeks intervention programme. The investigated cookies were produced at BreAD Unit- SEAFAST Center-IPB, Bogor. Results showed that nutrition composition calculated for 1000 kcal cookies were : protein 18.15 $\mathrm{g}$, fat $54.97 \mathrm{~g}$ and carbohydrate $110.51 \mathrm{~g}$. Food preference test carried out among 68 panelis pointed that more than $90 \%$ said the aroma of cookies were good and the texture were crunchy, more than two third stated that no after taste of $\mathrm{Fe}$ dan $\mathrm{Zn}$, and half of them like the yellow colour of the cookies. The compliance was not different for the investigated cookies group compared to the biscuit group at the first month of intervention programme, as the average supplement consumed by the study subject was $83 \%$ and $79 \%$ consecutively ( $p>0.05$ ). At the second and third months of intervention, the complinces were significantly different, in which the average supplement consumed were $82 \%$ as compared to $73 \%$ $(p<0.05)$; and $80 \%$ compared to $72 \%(p<0.05)$ respectively. Local based cookies have been accepted by the semi trained consumer during preference test and could be implemented as one alternative of food supplement provided for those of wasted children.

Keywords: wasting, ready to use food, RCT, food supplement, compliance 


\section{PENDAHULUAN}

$\mathrm{M}$ asalah kurang gizi akut pada anak balita di Indonesia masih cukup tinggi. Kurang gizi akut yaitu bila berdasarkan hasil pengukuran antropometri berat badan (BB) dan tinggi badan (TB) diperoleh nilai zskor BB/TB anak dibawah normal (<-2.0 SD) standar WHO. Kurang gizi akut dibedakan menjadi 2 kategori yaitu wasting (z-skor BB/TB $<-2.0$ dan $\geq-3.0 \mathrm{SD}$ ), dan severe wasting, atau yang biasa dikenal sebagai indikator gizi buruk, untuk kategori yang lebih berat yaitu bila z-skor BB/TB <-3.0 SD. Data Riskesdas 2010 menunjukkan hanya terjadi sedikit penurunan prevalensi masalah gizi akut dibandingkan data Riskesdas 2007 yaitu dari 13,6 persen menjadi 13,3 persen. Dari angka tersebut prevalensi wasting hanya turun sebesar 0,1 persen selama periode 3 tahun yaitu dari 7,4 persen menjadi 7,3 persen..$^{1,2}$

Mencegah terjadinya severe wasting sebaga indikator gizi buruk merupakan upaya penting yang harus dilakukan dalam rangka mencapai tujuan MDGs menurunkan prevalensi kurang gizi pada tahun 2015. Banyak faktor penyebab timbulnya kurang gizi maupun wasting, pada anak antara lain kurang asupan gizi, adanya penyakit infeksi serta faktor pengasuhan anak nyang kurang memadai. ${ }^{3}$ Gangguan gizi yang terjadi pada usia dini terbukti akan mengakibatkan gangguan pada perkembangan kecerdasan anak selain gangguan pada pertumbuhan fisik. 4,5 Oleh karena itu program perbaikan gizi khususnya yang dilakukan pada usia dini perlu mendapat perhatian agar tidak terjadi lost of generation.

Anak wasting memerlukan makanan yang khusus dengan komposisi gizi makanan berada antara anjuran untuk anak sehat dan makanan terapi untuk anak gizi buruk. Berbeda dengan anak gizi buruk yang sudah ada pedoman penatalaksanaan termasuk makanan yang harus diberikan, saat ini belum ada pedoman penatalaksanaan untuk anak wasting bagi petugas kesehatan yang menangani anak wasting di lapangan. ${ }^{6} \mathrm{Di}$ beberapa negara sudah digunakan Ready to Use Food (RUF) baik untuk terapi, Ready to Use Therapeutic Food (RUTF) maupun untuk pencegahan kurang gizi atau suplemen, Ready for Use
Food suplement (RUFs). Produk tersebut diproduksi secara komersial umumnya bentuk pasta dan telah banyak digunakan dalam mengatasi kurang gizi pada anak-anak terutama di Afrika.

Sampai saat ini di Indonesia belum tersedia makanan tambahan khusus untuk anak wasting. Jenis makanan tambahan yang biasa diberikan untuk anak balita kurang gizi termasuk anak wasting adalah MP-ASI bentuk biskuit atau tepung susu fullcream yang ada di pasaran atau makanan tambahan dalam bentuk makanan lokal. Penelitian ini merupakan penelitian uji klinik yang dilakukan pada anak usia di bawah tiga tahun (batita) dengan kategori wasting yang tertujuan untuk menilai penerimaan konsumen dan compliance anak batita wasting terhadap RUF bentuk cookies berbasis bahan lokal.

\section{METODE PENELITIAN}

Penelitian klinik/intervensi dengan disain Randomized Controlled Trial (RCT), paralel, single blind dilakukan di Klinik Gizi Pusat TTKEK Bogor (KG Bogor) tahun 2012. Kriteria inklusi subyek adalah: usia 6-35 bulan, tidak sedang terlibat dalam penelitian gizi lain, kategori wasting dengan $z$ skor $\mathrm{BB} / \mathrm{TB}$ antara 2.2 sampai -3.0 SD baku WHO 2005 dan bersedia berpartisipasi dalam penelitian. Kriteria eksklusi subyek adalah: menderita kelainan kongenital atau kelainan neurologik lainnya, alergi susu dan atau kacang kedele.

Besar sampel minimal berdasarkan perhitungan adalah 38 anak tiap kelompok dan dengan memperhitungkan kemungkinan drop out (DO), pada penelitian ini dipilih 43 anak tiap kelompok sehingga jumlah subyek dalam penelitian ini adalah 86 anak. ${ }^{7}$ Cara pemilihan sampel adalah melalui skrining yang dilakukan di 12 Puskesmas kantong masalah kurang gizi pada anak balita di wilayah Bogor sesuai data dari Dinas Kesehatan Kota Bogor dan Kabupaten Bogor. Skrining dilakukan pada anak balita yang dirujuk oleh posyandu ke Puskesmas. Anak yang memenuhi kriteria diminta kesediaan dari orang tua nya untuk berpartisipasi dalam penelitian, mengikuti penanganan rawat jalan di KG Bogor selama sekitar 4 bulan. Subyek direkrut dengan 
metode consecutive sampling sampai jumlah yang dibutuhkan terpenuhi. Alokasi sampel secara random menggunakan program computer dilakukan sebelum penelitian.

Kedua kelompok mengikuti penanganan rawat jalan di Klinik Gizi Bogor selama sekitar 4 bulan melalui kunjungan secara berkala yaitu: bulan 1 kunjungan 1x/minggu, bulan 2-3 kunjungan 1x2 minggu dan bulan ke 4 satu kali kunjungan. Pelayanan yang diterima oleh anak kedua kelompok tiap kunjungan sama meliputi: pemeriksaan kesehatan dan pengobatan sesuai penyakit, pengukuran antropometri (BB, PB atau TB), konseling gizi-kesehatan, penyuluhan stimulasi psikososial, makanan tambahan. Intervensi dalam bentuk makanan tambahan siap makan diberikan selama 3 bulan dengan kandungan energi sekitar 400 kkal/hari yaitu memenuhi sekitar 40-50 persen kebutuhan energi anak sehari. Kelompok intervensi mendapat makanan tambahan RUF berbasis bahan lokal dalam bentuk cookies sedangkan kelompok pembanding mendapat makanan tambahan fabrikan yaitu biskuit.

Wawancara dengan ibu/pengasuh anak dilakukan di rumah subyek menggunakan kuesioner. Data compliance dikumpulkan menggunakan ceklist yang dilakukan satu kali seminggu oleh kader dan tiap kunjungan ke KG Bogor oleh peneliti. Dalam penelitian ini, compliance diukur dari jumlah bahan intervensi yang dihabiskan oleh anak dalam periode tertentu dibandingkann dengan jumlah bahan yang diterima. Data compliance disajikan dalam angka persentase.

Makanan siap makan (RUF) berbasis bahan lokal dibuat di BReAD unit SEAFAST Center IPB dengan memperhatikan aturan Kemenkes RI dan Golden, dan SNI 01-7111.42005 tentang RUF dan MP-ASI siap santap. Uji mutu produk yang dihasilkan meliputi uji mutu kimia, mutu organoleptik, dan keamanan. Uji mutu kimia meliputi analisis proksimat terdiri dari analisis kandungan protein, lemak, serat makanan, karbohidrat dan kadar air. Uji organoleptik dilakukan pada cookies dengan menggunakan metode Hedonik terhadap warna, aroma, rasa, tekstur dan after taste dengan skor 1 sampai 10 . Nilai 1 artinya amat sangat tidak suka dan 10 amat sangat suka. Uji keamanan terdiri dari uji cemaran logam berat dan cemaran mikroba. Uji mutu dan keamanan cookies yang digunakan dalam penelitian dilakukan di laboratorium terpadu Insitut Pertanian Bogor (IPB) dan laboratorium Balai Besar Industri Argo (BBIA) yang telah terakreditasi KAN.

Formulasi makanan RUF dilakukan menggunakan Response Surface Methodology dengan bantuan software STAT EASE Design Expert 7, dengan faktor pembatas adalah energi 450-550 Kalori/100 gram bahan, protein 10-12 gram/100 gram bahan dan lemak $>30 \%$ dari total energi. Bahan dasar yang digunakan adalah tepung komposit berupa (tepung berassingkong/ubi jalar-kedelai $=60-20-20$ ) dari Gizi Masyarakat IPB (GM-IPB). Penambahan gula pasir, susu dan lemak nabati dilakukan untuk memenuhi kriteria formula yang diinginkan. Penggunaan mineral besi dan seng adalah mineral yang sudah dienkapsulasi. Mineral besi dan seng yang dienkapsulasi menggunakan besi sulfat dan seng sulfat dengan bahan penyalut terdiri dari maltodekstrin dan gum. Besi dan seng yang dienkapsulasi berdasarkan penelitian yang dilakukan oleh tim peneliti IPB mempunyai daya simpan cukup baik, terbukti dari pengamatan terhadap perubahan warna, aroma dan tekstur yang tetap stabil selama penyimpanan satu bulan. Nilai biologis besi dan seng yang dienkapsulasi juga cukup tinggi terbukti dari hasil pengamatan terhadap hewan coba. Mineral lain disesuaikan dengan persyaratan, demikian pula dengan vitamin disesuaikan dengan persyaratan yang ditetapkan Depkes dan Golden.8,9 Persetujuan Etik untuk penelitian ini diperoleh dari Komisi Etik Penelitian Kesehatan Badan Penelitian dan Pengembangan Kesehatan Kemkes RI dengan nomor 2012.

\section{HASIL}

\section{Makanan siap makan (RUF) Cookies dan biskuit fabrikan}

\section{Pembuatan cookies}

Proses pembuatan cookies yang digunakan melalui beberapa tahap sesuai SOP pembuatan cookies sampai diperoleh cookies yang diinginkan. Formulasi cookies dalam penelitian dilakukan dua tahap. Pada tahap pertama formulasi, diperoleh 4 formula yang memenuhi kriteria yang diinginkan dan dipilih 1 formula terbaik untuk percobaan pendahuluan 
pembuatan cookies. Pada percobaan pendahuluan secara teknis tidak terbentuk cookies yang baik secara fisik. Tahap kedua dilakukan reformulasi dan diperoleh satu formula yang akhirnya digunakan dalam produksi cookies. Komposisi bahan yang digunakan dalam pembuatan cookies terdiri dari (Tabel 1):

Tabel 1

Komposisi Bahan Makanan dalam Pembuatan Cookies

\begin{tabular}{lc}
\hline Bahan Makanan & Persentase \\
\hline - Tepung beras, tepung singkong, tepung kedele & 37,0 \\
- Tepung susu & 12,5 \\
- Lemak nabati & 28,0 \\
- Gula & 15,0 \\
- Telur ayam & 7,5 \\
\hline
\end{tabular}

Selain bahan tersebut ditambahkan beberapa vitamin dan mineral serta pengembang sesuai standar pembuatan cookies. Untuk mineral $\mathrm{Fe}$ dan $\mathrm{Zn}$ setelah dienkapsulasi dengan perbandingan 1:1 sebanyak $8 \mathrm{mg}$ tiap $100 \mathrm{~g}$ bahan.

Tahapan pembuatan cookies, secara garis besar meliputi tahapan pembuatan tepung, enkapsulasi mineral Fe dan Zn, pencampuran bahan penyusun, pembuatan adonan, pencetakan dan pemanggangan (pengovenan). Produksi cookies diawali dengan proses pembuatan bahan baku yang meliputi pembuatan tepung beras, tepung singkong dan tepung kedelai.

Tahapan pembuatan tepung beras pada prinsipnya adalah pencucian, perendaman 12 jam dan dikeringkan dengan drum dryer dan dihaluskan dengan discmill, diayak dan dikemas. Pembuatan tepung singkong diawali dengan pengupasan, pencucian, slicing, steaming dalam autoclave, pengeringan dengan drum dyer, dihaluskan dengan discmill, diayak dan dikemas. Pembuatan tepung kedelai dimulai dengan perendaman dengan air panas selama 12 jam, pengupasan dan pencucian, steaming dalam autoclave, pengeringan dengan drum dyer, dihaluskan dengan discmill, diayak dan dikemas.

Enkapsulasi mineral diawali dengan penimbangan mineral sesuai target, dilarutkan ke dalam air yang akan digunakan sebagai media enkapsulasi, dimasukkan sedikit demi sedikit bahan pengisi (maltodekstrin dan gum arab) sambil dihomogenisasi. Setelah homogen, kemudian dikeringkan dengan spray dryer dan terakhir dikemas.

Pembuatan cookies dimulai dengan penimbangan semua bahan sesuai dengan formula, kemudian dibuat adonan dengan menggunakan mixer, dicetak dan selanjutnya dioven dan terakhir dikemas menggunakan kemasan untuk makanan (metalize). Tiap kemasan terdiri dari 10 keping cookies dengan berat rata-rata $8,5 \mathrm{~g} / \mathrm{keping}$. Tiap anak mendapat 61/2 kemasan cookies seminggu.

\section{Penerimaan Panelis}

Untuk mengetahui daya terima terhadap cookies yang digunakan maka dilakukan uji organoleptik pada 68 orang panelis semi terlatih mahasiswa IPB di kampus IPB Bogor. Skor uji organoleptik tiap aspek yang diuji disajikan pada Tabel 2. Hasil uji organoleptik menunjukkan bahwa lebih dari 90 persen panelis menyatakan aroma cookies adalah harum dan teksturnya renyah. Sementara itu, sebanyak 75 persen panelis menyatakan bahwa rasa cookies adalah agak manis dan 50 persen panelis menyatakan bahwa warna cookies adalah agak kuning. Hasil uji after taste menunjukkan bahwa lebih dari dua per tiga panelis $(67,65 \%)$ menyatakan tidak terasa (tidak kuat) after taste setelah mencicipi cookies.

\section{Kandungan energi dan zat gizi cookies, keamanan, biskuit fabrikan}

Kandungan energi dan zat gizi formula cookies berdasarkan perhitungan dan berdasarkan hasil analisis proksimat disajikan pada Tabel 3. 
Tabel 2

Hasil Uji Organoleptik Cookies $(n=68)$

\begin{tabular}{lcccc}
\hline \multirow{2}{*}{ Aspek } & \multicolumn{2}{c}{ Tidak suka } & \multicolumn{2}{c}{ Suka } \\
\cline { 2 - 5 } & $\mathrm{n}$ & $\%$ & $\mathrm{n}$ & $\%$ \\
\hline Warna & 34 & 50,00 & 34 & 50,00 \\
Aroma & 5 & 7,35 & 63 & 92,65 \\
Rasa & 17 & 25,00 & 51 & 75,00 \\
Tekstur & 6 & 8,82 & 62 & 91,18 \\
After taste & 22 & 32,35 & 46 & 67,65 \\
\hline
\end{tabular}

Tabel 3

Kandungan Energi dan Zat Gizi Cookies per 100 gram

\begin{tabular}{lcc}
\hline \multicolumn{1}{c}{ Komponen } & Cookies * $^{*}$ & Formula ** \\
\hline Energi (kkal) & 509 & 520 \\
Air (g) & 3,18 & \\
Protein (g) & 9,24 & 11,4 \\
Lemak (g) & 27,98 & 27,8 \\
Karbohidrat (g) & 56,25 & 56,2
\end{tabular}

* Analisis proksimat berdasarkan berat basah

** Sesuai formula terpilih, perkiraan rendemen $89 \%$

Berdasarkan hasil perhitungan diketahui bahwa kandungan energi per 100 gram cookies adalah sebanyak 509 kkal. Hasil perhitungan berdasarkan formula dengan memperkirakan rendemen diperoleh kandungan energi sebesar 520 kkal. Air merupakan salah satu komponen bahan pangan yang dapat mempengaruhi tekstur dan daya tahan bahan pangan selama penyimpanan. Hasil analisis menunjukkan bahwa kandungan air cookies adalah sebesar 3,18 persen.

Kandungan proein cookies berdasarkan hasil analisis proksimat adalah sebesar 9,24 persen. Berdasarkan hasil perhitungan kandungan protein per 100 gram cookies adalah 11,4 persen, lebih tinggi dibandingkan hasil analisis proksimat. Kandungan lemak cookies berdasarkan hasil analisis adalah sebesar 27,98 persen. Berdasarkan hasil perhitungan kandungan lemak per 100 gram cookies adalah 27,8 persen. Untuk kandungan karbohidrat cookies berdasarkan analisis proksimat adalah sebesar 56,25 persen, sedangkan berdasarkan hasil perhitungan didapatkan kandungan karbohidrat per 100 gram cookies adalah 56,2 persen.

Analisis mineral hanya dilakukan untuk $\mathrm{Fe}$ dan $\mathrm{Zn}$. Hasil analisis menunjukkan bahwa kandungan Fe cookies adalah sebesar 10,61 $\mathrm{mg} / 100 \mathrm{~g}$ dan kandungan $\mathrm{Zn}$ adalah sebesar $5,25 \mathrm{mg} / 100 \mathrm{~g}$ cookies.

\section{Keamanan}

Untuk memperoleh makanan yang aman dikonsumsi, maka perlu dilakukan uji keberadaan pencemar, baik logam berat maupun mikroorganisme. Adapun logam berat yang dianalisis meliputi $\mathrm{Pb}$ (lead) dan $\mathrm{Hg}$ (mercury). Hasil analisis kandungan logam berat menunjukkan bahwa kandungan $\mathrm{Pb}$ (lead) cookies adalah kurang dari $0 ., 01 \mathrm{ppm}$ dan $\mathrm{Hg}$ (mercury) adalah kurang dari 0.0002 ppm.

Selain analisis logam berat, untuk memperoleh makanan yang aman dengan kadar pathogen dan toksin makanan yang dapat diterima, maka ada beberapa tahapan yang harus dilakukan dalam memproduksi makanan. Tahapan tersebut meliputi 
pencegahan kontaminasi mikroorganisme dalam makanan, pencegahan pertumbuhan mikroorganisme dan/atau pembentukan toksin dalam makanan, serta pengurangan mikroorganisme penyebab penyakit (pathogen). Ada beberapa jenis bakteri yang terkait dengan keracunan makanan, antara lain adalah Salmonella, Eschericha coli, dan Coliform. Uji mikrobiologis yang dilakukan meliputi total plate count (TPC), Salmonella, E. coli dan Coliform. TPC dapat menggambarkan total mikroorganisme yang ada dalam cookies. Hasil analisis mikrobiologis yang dilakukan pada cookies disajikan pada Tabel 4.

Pada Tabel 3 dapat dilihat bahwa TPC cookies adalah $6.8 \times 10^{2}$ koloni/gram. Hasil analisis juga menunjukkan bahwa tidak terdapat Salmonella dan E-Coli pada cookies. Tabel diatas juga menunjukkan bahwa Coliform dalam cookies kurang dari 3,0 MPN/gram.

Tabel 4

Hasil Analisis Mikrobiologis Cookies

\begin{tabular}{lc}
\hline Jenis mikroba & Jumlah \\
\hline TPC (koloni/g) & $6,8 \times 10^{2}$ \\
Salmonella & Negatif \\
E. coli & Negatif \\
Coliform $(\mathrm{MPN} / \mathrm{g})$ & $<3,0$ \\
\hline
\end{tabular}

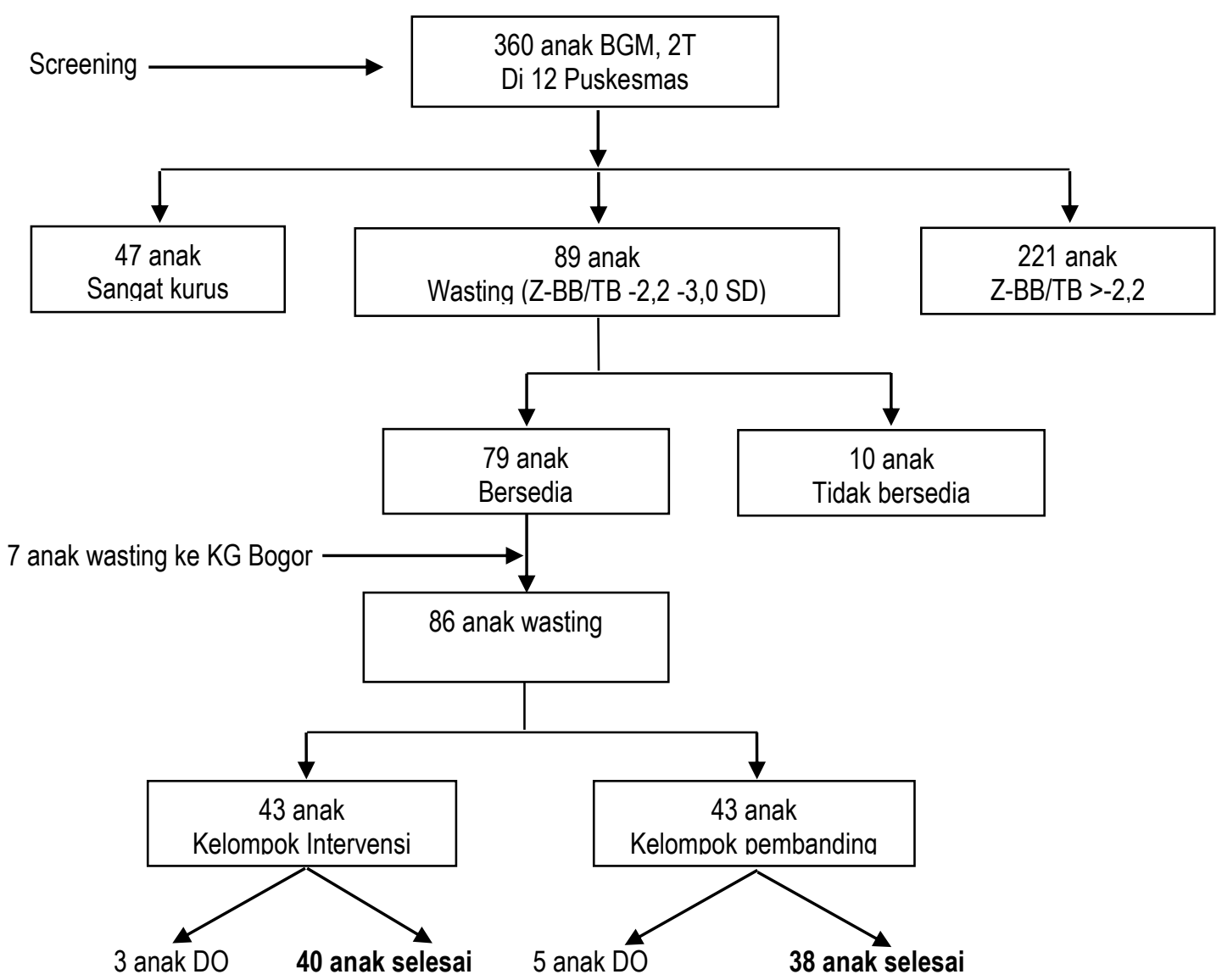

Gambar 1

Kerangka Sampel Penelitian 


\section{Biskuit fabrikan}

Biskuit yang diberikan pada anak wasting kelompok pembanding adalah jenis biskuit marie yang ada di pasaran. Biskuit tersebut terdaftar dengan nomor register: BPOM RI MD 627110008783 yang diproduksi oleh salah satu fabrik biskuit di Bandung. Komposisi bahan biskuit adalah: tepung terigu, mentega, susu, gula, garam dan perasa vanila. Untuk memudahkan dalam pemberian kepada subyek penelitian, biskuit dipesan dengan berat $100 \mathrm{~g}$ tiap kemasan yang berisi 14 keping biskuit dengan menggunakan kemasan polos metalize. Kandungan gizi tiap $100 \mathrm{~g}$ biskuit yang dihitung berdasarkan informasi yang tertera pada label adalah sebagai berikut: energi $=400 \mathrm{kkal}$, protein $=8,5 \mathrm{~g}$, lemak $=8,5$ $\mathrm{g}$, karbohidrat $=71 \mathrm{~g}$.

Tiap anak akan mendapat satu kemasan biskuit sehari, atau 7 kemasan seminggu sesuai dengan ketentuan ISO energi yang ditetapkan dalam penelitian ini.

\section{Karakteristik sampel}

Sesuai dengan kehadirannya di klinik, nama anak dimasukkan kedalam tabel random yang telah diperoleh melalui randomisasi menggunakan software. Dari 43 anak tiap kelompok, terdiri dari 20 anak laki-laki dan 23 anak perempuan. Kerangka sampel penelitian disajikan pada Gambar 1.
Dari 86 anak yang berhasil direkrut pada awal penelitian, 8 anak drop out dengan rincian: 3 anak dari kelompok intervensi dan 5 anak dari kelompok pembanding. Selanjutnya pada makalah ini hanya akan disajikan data dari 78 anak yang mengikuti penelitian selama 4 bulan terdiri dari 40 anak dari kelompok intervensi dan 38 anak dari kelompok pembanding. Sesuai dengan perhitungan sampel yang digunakan dalam penelitian ini, jumlah sampel minimal tiap kelompok yaitu 38 anak sudah terpenuhi sehingga analisis yang digunakan telah memenuhi syarat perhitungan statistik.

Pada Tabel 5 disajikan sebaran anak menurut jenis kelamin dan kelompok umur. Tampak bahwa proporsi anak perempuan pada kelompok intervensi lebih banyak dibandingkan anak laki-laki (52,5\% dibandingkan 47,5\%), sebaliknya pada kelompok pembanding proporsi anak laki-laki lebih banyak dibandingkan anak perempuan $(52,6 \%$ dibandingkan 47,4\%). Berdasarkan kelompok umur, tampak bahwa sebagian besar anak pada kedua kelompok termasuk kelompok usia 6-23 bulan. Usia terrendah adalah 6 bulan dan tertinggi 35 bulan. Tidak ada perbedaan rerata umur kedua kelompok pada awal mengikuti penelitian yaitu pada kelompok intervensi $(22,38 \pm 7,198)$ bl dan pada kelompok pembanding adalah $(20,34 \pm 6.274) \mathrm{bl}(\mathrm{t}=1,327$, $d=76, p=0,188)$.

Tabel 5

Sebaran Anak menurut Jenis Kelamin dan Kelompok Umur

\begin{tabular}{lcccc}
\hline & \multicolumn{4}{c}{ Kelompok subyek } \\
\cline { 2 - 5 } \multicolumn{1}{c}{ Uraian } & \multicolumn{2}{c}{ Intervensi } & \multicolumn{2}{c}{ Pembanding } \\
\cline { 2 - 5 } & $\mathrm{n}$ & $\%$ & $\mathrm{n}$ & $\%$ \\
\hline Perempuan : & 21 & 52,5 & 18 & 47,4 \\
$6-23$ bulan & 13 & 32,5 & 11 & 28,9 \\
24 - 35 bulan & 8 & 20,0 & 7 & 18,5 \\
Laki-laki : & 19 & 47,5 & 20 & 52,6 \\
$6-23$ bulan & 12 & 30,0 & 14 & 36,8 \\
24 - 35 bulan & 7 & 17,5 & 6 & 15,8 \\
\hline Total & 40 & 100,0 & 38 & 100,0 \\
\hline
\end{tabular}

Berdasarkan urutan anak dalam keluarga, diketahui bahwa sebagian besar anak pada kelompok intervensi merupakan anak pertama yaitu 42,5 persen, sedangkan pada kelompok pembanding proporsi terbesar adalah anak kedua yaitu 36,21 persen. Tingkat pendidikan 
formal tertinggi ibu relatif cukup. Pada kelompok intervensi proporsi tertinggi pendidikan ibu adalah SLTP yaitu 45 persen sedangkan pada kelompok pembanding terlihat untuk SLTP dan SLTA dengan proporsi yang hampir sama yaitu 34,2 persen dan 36,9 persen. Tingkat pendidikan ayah dengan proporsi tertinggi adalah SLTA yaitu 52,5 persen pada kelompok intervensi dan 42,2 persen pada kelompok pembanding. Pekerjaan utama kepala keluarga atau ayah pada kedua kelompok adalah sebagai buruh atau sebagai pedagang kecil. Hanya sebagian kecil ibu yang bekerja di luar rumah. Dengan demikian ibu umumnya sebagai ibu rumah tangga yang mempunyai waktu cukup untuk mengasuh anak dan mengurus keluarga di rumah.

\section{Compliance}

Data compliance dikumpulkan oleh kader melalui kunjungan sekali seminggu ke rumah sampel dicatat dalam buku catatan anak. Definisi compliance dalam penelitian ini adalah jumlah makanan intervensi, yaitu cookies untuk kelompok intervensi dan biskuit untuk kelompok pembanding, yang dihabiskan oleh anak pada setiap pemberian. Data compliance disajikan dalam rerata persentase tiap bulan menurut kelompok intervensi selama penelitian dapat dilihat pada Tabel 6. Kepatuhan sampel untuk mengkonsumsi makanan tambahan yang diberikan cukup bervariasi diantara anak maupun diantara kelompok.

Tabel 6

Compliance Kelompok Intervensi dan Pembanding Selama Penelitian

\begin{tabular}{|c|c|c|c|}
\hline \multirow{2}{*}{ Uraian } & \multicolumn{2}{|c|}{ Mean \pm SD } & \multirow{2}{*}{$\mathrm{p}$} \\
\hline & Intervensi & Pembanding & \\
\hline \multicolumn{4}{|c|}{ Compliance (\%) : } \\
\hline Bulan 1 & $83,44 \pm 12,55$ & $9,01 \pm 12.46$ & 0,125 \\
\hline Bulan 2 & $81,77 \pm 17,13$ & $73,21 \pm 16.61$ & 0,029 * \\
\hline Bulan 3 & $80,21 \pm 16,61$ & $72,20 \pm 16.73$ & 0,039 * \\
\hline
\end{tabular}

Compliance anak batita wasting pada bulan pertama tidak berbeda antara kelompok yang mendapat cookies dengan biskuit. Rerata makanan tambahan intervensi yang dapat dihabiskan pada kelompok intervensi dengan cookies adalah 73 persen sedangkan yang mendapatkan biskuit fabrikan 74 persen $(p>0,05)$. Pada bulan kedua terdapat perbedaan compliance kedua kelompok dimana rerata cookies yang dihabiskan 80 persen sedangkan pada kelompok biskuit adalah 68 persen $(p<0,05)$. Pada bulan ketiga rerata cookies yang dihabiskan 75 persen dan biskuit 62 persen $(p<0.05)$.

\section{BAHASAN}

Makanan intervensi yang digunakan dalam uji klinik ini dibuat di BReAD Unit SEAFAST CENTER IPB Bogor. Bahan baku makanan siap makan atau RUF dalam penelitian ini adalah tepung komposit yang dihasilkan oleh tim peneliti dari Gizi Masyarakat IPB. Bahan dasar tersebut adalah non terigu, terdiri dari tepung beras, tepung singkong dan tepung kedele dengan mineral $\mathrm{Fe}$ dan $\mathrm{Zn}$ yang dienkapsulasi. ${ }^{11}$ Cookies yang dibuat dalam penelitian ini menggunakan tepung komposit tersebut dengan ditambahkan tepung susu, lemak nabati, gula dan telur serta bahan tambahan lain yaitu pengembang dan vanila.

Komposisi gizi yang dihitung berdasarkan formulasi yang dibuat, agak berbeda dengan hasil analisis proksimat khususnya untuk protein. Kadar protein hasil analisis adalah 9,24 persen yaitu lebih rendah dibandingkan perhitungan yaitu 11,4 persen. Dengan demikian, kandungan protein yang diperoleh lebih rendah dari yang direncanakan dalam formula yaitu antara (10-12) persen. Berdasarkan anjuran yang ditetapkan WHO, kandungan protein RUF 24-26 g per 1000 kkal. ${ }^{9}$ Meskipun belum memenuhi anjuran yang ditetapkan oleh WHO, akan tetapi kandungan protein cookies sudah memenuhi persyaratan 
yang ditetapkan melalui kepmenkes tahun 2007 yaitu 9 persen. ${ }^{8} \mathrm{Hal}$ ini bisa terjadi karena kandungan gizi bahan makanan dapat dipengaruhi oleh kondisi bahan, varietas, asal bahan dan lain-lain. Oleh karena itu untuk mendapatkan komposisi zat gizi yang diinginkan sesuai anjuran komposisi RUF dari WHO, sebaiknya dilakukan analisis terhadap bahan yang digunakan untuk pembuatan suatu produk makanan intervensi.

Protein yang terlalu tinggi akan memberatkan fungsi ginjal apabila tidak sesuai kebutuhan. Untuk anak wasting dianjurkan tidak lebih dari 15 persen energi berasal dari protein. $^{12}$

Berbeda dengan protein, kandungan lemak cookies yaitu 27,98 persen berdasarkan analisis proksimat yaitu sedikit lebih tinggi dari anjuran RUF untuk anak wasting yaitu 35-45 persen energi berasal dari lemak. ${ }^{13}$ Hasil analisis menununjukkan bahwa energi yang berasal dari lemak pada cookies yaitu 49 persen. Dibandingkan dengan RUTF yang mengandung hampir 60 persen energi berasal dari lemak maka kandungan lemak pada cookies adalah lebih rendah. Kandungan lemak yang sangat tinggi pada RUTF diperlukan karena makanan terapi tersebut ditujukan untuk anak severe wasting yang diberikan melalui perawatan secara rawat jalan di masyarakat. ${ }^{14}$

RUTF yang merupakan makanan terapi pada anak gizi buruk, tidak tepat bila diberikan pada anak wasting karena komposisi gizi RUTF sangat tinggi, lemak dan protein. Pada F100 yang merupakan formula

standar dalam managemen gizi buruk, 50 persen energi berasal dari lemak, sedangkan pada RUTF 50-60 persen energi dari lemak. ${ }^{13}$ Menurut Golden ${ }^{8}$, anak wasting memerlukan makanan yang khusus dengan komposisi gizi makanan berada antara anjuran untuk anak sehat dan makanan terapi pada anak gizi buruk. Kebutuhan energi dianjurkan 115 $\mathrm{kkal} / \mathrm{kg} \mathrm{BB} / \mathrm{hari}$. Kadar lemak yang tinggi pada makanan untuk anak wasting memungkinkan makanan jadi padat gizi. Hal ini sudah dipenuhi oleh cookies yang dibuat dalam penelitian ini.

Untuk memperoleh makanan yang aman dikonsumsi, termasuk makanan intervensi yang akan diberikan untuk anak wasting, makanan tersebut harus memenuhi persyaratan tertentu terutama keberadaan pencemar, baik logam berat maupun mikroorganisme. Hasil analisis yang dilakukan pada cookies menunjukkan bahwa kandungan $\mathrm{Pb}$ (lead) cookies adalah kurang dari 0,01 ppm dan $\mathrm{Hg}$ (mercury) adalah kurang dari 0,0002 ppm. Kandungan $\mathrm{Pb}$ dan $\mathrm{Hg}$ dalam cookies masih jauh lebih rendah dari persyaratan BPOM maupun kementerian kesehatan dimana batas maksimal $\mathrm{Pb}$ dan $\mathrm{Hg}$ dalam biscuit MP-ASI masing-masing adalah 0,3 ppm dan 0,03 ppm. ${ }^{15,16}$

Analisis mikrobiologis yang dilakukan meliputi TPC, dan uji cemaran Salmonella, $E$. coli dan Coliform. TPC dapat menggambarkan total mikroorganisme yang ada dalam kukis. TPC cookies jauh di bawah standar yang ditetapkan, yaitu $1.0 \times 10^{5}$ koloni/gram. Hal ini mengindikasikan bahwa cookies tersebut adalah aman untuk dikonsumsi. Salmonella, E. coli dan Coliform. merupakan bakteri patogen yang berbahaya apabila terdapat dalam makanan bayi. Habitat utama Salmonella adalah dalam saluran usus halus hewan dan manusia. Bakteri tersebut bersifat mudah rusak oleh panas. Hasil analisis terhadap cookies menunjukkan bahwa tidak terdapat Salmonella dan Eschericha coli pada cookies. Coliform jauh lebih rendah daripada standar yang ditetapkan. ${ }^{15,16}$ Kedua hasil uji keamanan terhadap pencemar mengindikasikan bahwa cookies tersebut adalah aman untuk dikonsumsi. Hal ini sangat penting karena RUF dalam bentuk cookies ini diberikan untuk anak batita kurang gizi kategori wasting.

Setelah diketahui bahwa cookies aman untuk dikonsumsi, perlu dilakukan uji organoleptik untuk mengetahui apakah produk tersebut dapat diterima oleh konsumen. Pada penelitian ini dilakukan uji pada panelis semi terlatih yang merupakan mahasiswa jurusan Gizi Masyarakat di IPB. Hasil uji organoleptik menunjukkan bahwa panelis dapat menerima aroma dasn sebagian besar panelis menyatakan aroma cookies adalah harum dengan teksturn yang renyah. Rasa cookies panelis menyatakan adalah agak manis dan warna cookies adalah agak kuning. Hasil uji after taste menunjukkan bahwa sebagian besar menyatakan tidak terasa (tidak kuat) after taste setelah mencicipi cookies. Secara keseluruhan dapat dikatan bahwa cookies dapat diterima oleh konsumen. 
Salah satu cara untuk mengurangi ketergantungan suatu negara terhadap bahan import adalah dengan menggunakan bahan makanan lokal untuk membuat makanan tambahan bagi anak balita. Ini dapat dilakukan pada pembuatan RUF atau makanan siap makan, yaitu makanan yang dapat langsung dimakan tanpa harus dimasak. Keuntungan lain dari penggunaan bahan lokal adalah rasa yang sudah dikenal oleh anak. Penggunaan bahan lokal pada gilirannya juga akan memberikan pengaruh positif terhadap sektor pertanian dalam negeri. Pada tahun 2010, tim peneliti IPB telah menghasilkan tepung komposit yang terdiri dari bahan lokal beras-ubi jalar/singkong-kedelai dalam bentuk biasa dan instan sebagai bahan dasar pembuatan MPASI. Tepung komposit tersebut juga difortifikasi dengan mineral besi dan seng yang dienkapsulasi dan terbukti dapat meningkatkan secara signifikan kadar besi dan seng dalam serum darah tikus. ${ }^{11}$

Penggunaan Fe dan Zn secara bersamaan dapat menimbulkan terjadinya interaksi, di mana yang satu menghambat yang lain. Penambahan $\mathrm{Fe}$ juga mengurangi daya terima karena warna makanan menjadi kurang menarik dan menimbulkan bau besi yang khas. Oleh karena itu, perlu dilakukan proses mikroenkapsulasi kedua mineral yang diharapkan dapat digunakan untuk mengatasi kekurangan mineral tersebut. Mineral besi berperan penting dalam pembentukan hemoglobin yang merupakan komponen utama sel darah merah. Fungsi utama sel darah merah adalah untuk transportasi oksigen dan zat gizi ke seluruh tubuh. Kekurangan besi akan mengakibatkan seseorang menderita anemia, selain dapat menimbulkan gangguan pertumbuhan.

Penelitian ini merupakan clinical trial dengan waktu yang diperlukan dalam keterlibatan setiap anak wasting terpilih cukup lama yaitu sekitar 4 bulan. Dengan demikian kemungkinan ada subyek yang drop out telah dipertimbangkan sejak perencanaan. Jumlah subyek yang direkrut pada awal penelitian sebanyak 86 anak masing-masing 43 anak untuk tiap kelompok. Sebanyak 78 anak mengikuti sampai selesai 4 bulan intervensi, karena 8 anak drop out ( 3 anak dari kelompok intervensi dan 5 anak dari kelompok pembanding). Dalam artikel ini analisis dilakukan pada 78 anak yang mengikuti penelitian secara penuh selama 4 bulan. Hasil penelitian terhadap perubahan status gizi, kenaikan berat badan dan status kesehatan lainnya disajikan pada artikel lain. Dalam artikel ini dibahas compliance subyek terhadap bahan intervensi yang diberikan.

Compliance merupakan faktor penting dalam suatu uji klinis. Kepatuhan subyek mengkonsumsi makanan tambahan yang diberikan cukup bervariasi diantara anak maupun diantara kelompok. Kebiasaan jajan makanan ringan merupakan salah satu faktor yang mempengaruhi compliance terhadap bahan intervensi yang harus dihabiskan tiap hari. Definisi compliance dalam penelitian ini adalah jumlah makanan intervensi, yaitu cookies untuk kelompok intervensi dan biskuit untuk kelompok pembanding, yang dihabiskan oleh anak pada setiap pemberian. Kepatuhan sampel untuk mengkonsumsi makanan tambahan yang diberikan cukup bervariasi diantara anak maupun diantara kelompok.

Data yang diperoleh dalam penelitian ini menunjukkan bahwa compliance cookies lebih tinggi dibandingkan biskuit fabrikan yaitu pada bulan kedua dan ketiga intervensi. Pada bulan pertama tidak ada perbedaan compliance pada kedua kelompok yaitu rerata pada kelompok intervensi dengan cookies adalah 73\% sedangkan yang mendapatkan biskuit fabrikan 74 persen $(p>0.05)$. Hal ini mungkin dipengaruhi juga oleh kondisi klinis anak selain anak belum terbiasa dengan makanan yang baru. Pada bulan kedua terdapat perbedaan compliance kedua kelompok dimana rerata cookies yang dihabiskan 80 persen sedangkan pada kelompok biskuit adalah 68 persen $(p<0.05)$. Pada bulan ketiga rerata cookies yang dihabiskan 75 persen dan biskuit 62 persen $(p<0.05)$. Hal ini kemungkinan disebabkan karena anak sudah terbiasa dengan bentuk dan rasa makanan intervensi bentuk cookies berbasis bahan lokal selain karena faktor kesehatan.

Penanganan anak gizi buruk yang dilakukan secara komprehensif meliputi aspek kesehatan, gizi dan diikuti oleh stimulasi psikososial terbukti dapat memulihkan status gizi dan kesehatan anak. Penanganan secara comprehensif juga diperlukan dalam perawatan rawat jalan anak wasting untuk mencegah terjadinya severe wasting atau gizi buruk. 
Pemberian makanan dengan komposisi khusus dalam bentuk RUF dapat dilakukan di Puskesmas.

Beberapa alasan seperti: bosan karena 1 macam makanan untuk 3 bulan intervensi, waktu sakit nafsu makan anak menurun, anak tidak suka makanan manis seperti biskuit atau cookies, anak banyak jajan makanan yang gurih atau asin. Oleh karena itu perlu diberikan makanan tambahan yang bervariasi untuk anak dengan kualitas yang sama dalam artian kandungan gizi, agar compliance meningkat.

Faktor compliance merupakan aspek penting yang dikumpulkan dalam suatu penelitian klinik dengan memberikan intervensi. Alasan sudah bosan merupakan pernyataan yang dikemukakan sebagai faktor penyebab rendahnya konsumsi cookies dan biskuit pada sebagian anak karena tidak ada variasi rasa dan bentuk makanan selama penelitian.

\section{SIMPULAN DAN SARAN}

\section{Simpulan}

Dari tulisan ini dapat disimpulkan bahwa cookies berbasis bahan lokal dapat diterima konsumen berdasarkan penilaian aroma, warna, rasa dan tekstur.

\section{Saran}

RUF dalam bentuk cookies berbasis bahan lokal yang dihasilkan dalam penelitian ini dapat digunakan sebagai alternatif makanan tambahan bagi anak batita wasting.

\section{UCAPAN TERIMA KASIH}

\section{terima kasih disampaikan kepada:}

1. SEAFAST CENTER IPB khususnya Manager dan staf BreAD Unit atas kerjasama yang baik untuk memproduksi cookies tepat waktu.

2. Dinas Kesehatan di wilayah Kabupaten Bogor dan Kota Bogor atas izin, bantuan dan kerjasama yang baik dalam pelaksanaan screening anak wasting di puskesmas.

3. Keluarga anak batita wasting yang telah berpartisipasi dalam penelitian sampai selesai penanganan di Klinik Gizi Bogor selama 4 bulan.

4. Kader posyandu atas bantuan dalam memantau kepatuhan subyek untuk mengkonsumsi bahan intervensi yang diberikan selama penelitian.

\section{RUJUKAN}

1. Departemen Kesehatan RI. Laporan Hasil RISKESDAS Indonesia tahun 2010. Jakarta: Badan Litbangkes Kemkes RI, 2010.

2. Departemen Kesehatan RI. Laporan Hasil RISKESDAS Indonesia tahun 2007. Jakarta: Badan Litbangkes Depkes RI, 2008.

3. UNICEF. The state of the World's children. Oxford: Oxford University Press, 1998

4. Grantham-McGregor, SM, Pollitt, Wachs, $D$, Meisel, SJ et al. Effects of health and nutrition on cognitive and behavioral development in children in the first three years of life. Food and Nutrition Bulletin. 1999;20(1): 53-75.

5. Arnelia dkk. Gizi Buruk pada Usia Dini dan Dampaknya terhadap Tingkat Kecerdasan dan Keragaan Sekolah Anak. Media Gizi \& Keluarga. 2002; 26(1): 9-19

6. Kementerian Kesehatan RI. Pedoman Pelayanan Anak Gizi Buruk.Jakarta: Direktorat Bina Gizi, 2011.

7. Lemeshow S, Hosmer D, Klar J, Lwanga S. Adequacy of Sample Size in HealthStudies.New York: John Wiley \& Sons, Chicester, 1990.

8. Keputusan Menkes RI no. 224/Menkes/SK/II/2007. Spesifikasi Teknis Makanan Pendamping Air Susu Ibu (MPASI). Jakarta: KemenKes, 2007

9. Golden, MH. Proposed recommended nutrient densities for moderately malnourished children. Food and NutritionBulletin, 2009;30:267-342.

10. Dewan Standardisasi Nasional. SNI 012973-1992 : Mutu dan Cara Uji Biskuit. Jakarta: Dewan Standardisasi Nasional, 1992.

11. Kustiyah, L, Mira Dewi dan Faisal Anwar. Mikroenkapsulasi $\mathrm{Fe}$ dan $\mathrm{Zn}$ dalam pembuatan makanan tambahan balita gizi kurang. Laporan penelitian.Bogor:IPB, 2010.

12. Briend A and Zita WP. Dietary management of moderate malnutrition: Time for a change. Food and Nutrition Bulletin. 2009;30:S265-266. 
13. Michaelsen KF, Camilla Hoppe, Nanna Roos, Pernille Kaestel, Maria Stougaard et al. Choice of foods and engredients for moderately malnourished children 6 months to 5 years of age. Food and Nutrition Bulletin. 2009:30:S343-404.

14. WHO, WFP, UNSCN and UNICEF. Community Based Management of Severe Acute Malnutrition : A Joint Statement by the WHO, WFP, UNSCN and UNICEF. Geneva: WHO, 2007.

15. Badan POM RI.Peraturan Nomor HK.00.06.1.52.4011: Penetapan Batas Maksimum Cemaran Mikroba dan Kimia dalam Makanan. Jakarta: Badan Pengawasan Obat dan Makanan Republik Indonesia, 2009.
16. Badan SNI.SNI 7388: Batas Maksimum Cemaran Mikroba dalam Pangan.Jakarta: Badan Standarisasi Nasional Indonesia,2009.

17. Shoham $J$ and $A$ Duffield. Proceedings of the WHO/UNICEF/WFP/UNHCR Consultation on the Management of Moderate Malnutrition in Children under 5 years of Age. Food Nutr Bull, 2009;30:S464-474.

18. Arnelia,Irawati,Lamid, A, Fajarwati, $T$ and Rahmawati, R. Pengaruh pemulihan gizi buruk rawat jalan secara komprehensif terhadap status gizi anak batita. Penelitian Gizi dan Makanan. 2010:33(2):12-20. 